\title{
Рейтинг районов Бугульминско-Белебеевской возвышенности Республики Башкортостан по недревесной продукции леса
}

Хисамов Р.Р., Мазуркин П.М., Рахматуллина И.Р.

Введение. Бугульминско-Белебеевская возвышенность в пределах Республики Башкортостан занимает западную приподнятую окраину республики и является одним из наиболее промышленно развитых, густонаселенных и лесодефицитных районов (рис. 1). По лесорастительному районированию территория отнесена к лесостепной зоне и лесостепному району Европейской части Российской Федерации. Общая площадь лесного фонда 314,0 тыс. га. (Лесохозяйственные регламенты, 2008).

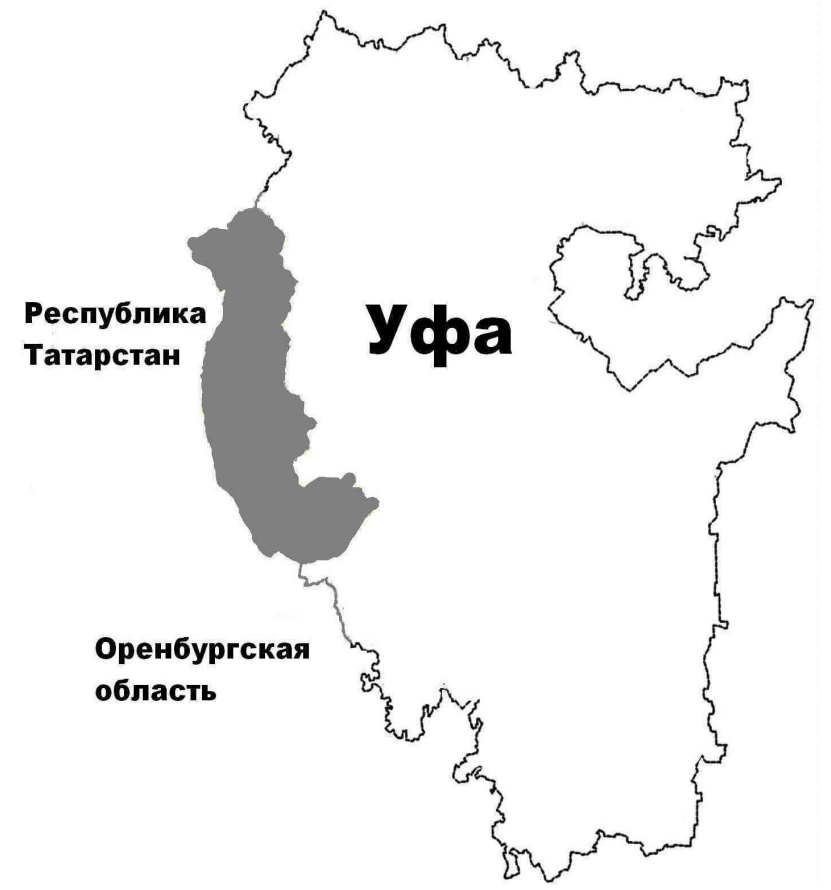

Рисунок 1. Бугульминско-Белебеевская возвышенность в пределах территории Республики Башкортостан

Помимо средообразующей ценности лесные насаждения возвышенности имеют важное значение для местного населения как источника побочной продукции леса. Для анализа использования недревесной продукции леса были проанализированы следующие показатели лесного фонда: заготовка дикорастущего плодовоягодного и лекарственного сырья; объемы заготовок сена на лесных сенокосных угодьях; лесное пчеловодство объем медосбора с пасек, количество пчелосемей на пасеках. Исходный материал для работы выбирался из годовых отчетов лесничеств за 8 лет (20062013 гг.) $[6,7]$.

В природе всё взаимно увязано, поэтому любой учитываемый фактор влияет на остальные факторы (бинарные отношения), включая на самого себя (ранговые распределения монарных отношений). Причем сами 17 факторов заранее были выбраны по интуиции.

Вначале рассматриваются ранговые распределения значений у каждого фактора. По ним можно оценивать рейтинг 7 (минимум) районов [1]. Такой рейтинг позволяет оценивать эффективность деятельности каждого района.

Из-за периода времени за 8 лет динамики показателей были определены средние значения из данных таблицы 1 и таблицы 2 (всего 17 факторов) по 7 районам. Факторный анализ [1-5] нами проведен с применением детерминированной общей закономерности в виде суммы двух биотехнических законов

$$
y_{m}=y_{m 1}+y_{m 2}, y_{m 1}=a_{1} x^{a_{2}} \exp \left(-a_{3} x^{a_{4}}\right), y_{m 2}=a_{5} x^{a_{6}} \exp \left(-a_{7} x^{a_{8}}\right),
$$

где $y_{m}$ - тренд показателя, $x$ - объясняющая переменная, $a_{1} \ldots a_{8}$ - параметры модели (1), получаемые в CurveExpert (URL: http://www.curveexpert.net/). 
Для выявления волновых членов дополнительно к тренду необходимо множество из не менее 20 районов.

Исходные данные. Табличные данные для статистического моделирования [6] даны в таблице 1 и таблице 2.

Таблица 1

Распределение земель по районам на Бугульминско-Белебеевской возвышенности по категориям земель, тыс.га

\begin{tabular}{|c|c|c|c|c|c|c|c|c|c|}
\hline \multirow[b]{2}{*}{ Район } & \multirow[b]{2}{*}{\begin{tabular}{|c|} 
Общая \\
площадь \\
$S$
\end{tabular}} & \multirow{2}{*}{$\begin{array}{c}\text { Земли сельско- } \\
\text { хозяйственного } \\
\text { назначения } \\
S_{c x y}\end{array}$} & \multicolumn{6}{|c|}{ Земли лесного фонда } & \multirow[b]{2}{*}{$\begin{array}{c}\text { Прочие } \\
\text { земли } \\
S_{n p}\end{array}$} \\
\hline & & & $\mid \begin{array}{c}\text { лесопок- } \\
\text { рытые } \\
S_{л n}\end{array}$ & $\begin{array}{c}\text { ре- } \\
\text { дины } \\
S_{p}, \text { га }\end{array}$ & \begin{tabular}{|c} 
вы- \\
рубки \\
$S_{\theta}$, га
\end{tabular} & $\begin{array}{c}\text { прога- } \\
\text { лины } \\
S_{n p}, \\
\text { га }\end{array}$ & $\begin{array}{c}\text { сено- } \\
\text { косы } \\
S_{c}\end{array}$ & $\begin{array}{c}\text { паст- } \\
\text { бища } \\
S_{n}\end{array}$ & \\
\hline Бакалин & & & & 39 & 1063 & 176 & 1.543 & 1.011 & 11.490 \\
\hline Белебеев & 5.58 & 107.82 & 63.093 & 65 & 889 & 279 & 1.328 & 1.046 & 8.937 \\
\hline Бижбулян & 213.39 & & & 91 & 276 & 381 & 0.707 & 0.524 & 18.815 \\
\hline Ермеке & 143.43 & 109 & & 15 & 94 & 104 & 0.415 & 0.510 & 12.114 \\
\hline Миякин & 205. & 150.82 & 30.329 & 104 & 265 & 214 & 1.195 & 0.636 & 14.396 \\
\hline ТуймазІ & & & & 97 & 1186 & 524 & 2.669 & 1.545 & 24.577 \\
\hline Шаранский & 138.42 & 95.75 & 33.780 & 24 & 431 & 50 & 0.423 & 0.403 & 7.548 \\
\hline
\end{tabular}

Таблица 2

Показатели заготовки побочной продукции леса по районам на Бугульминско-Белебеевской возвышенности

\begin{tabular}{|c|c|c|c|c|c|c|c|c|}
\hline Район & $\begin{array}{c}\text { Площадь } \\
\text { лесного } \\
\text { фонда } \\
S_{\text {ЛФ }} \text {, тыс. } \\
\text { га }\end{array}$ & $\begin{array}{c}\text { Площадь } \\
\text { липня- } \\
\text { ков } \\
S_{л}, \text { тыс. га }\end{array}$ & $\begin{array}{c}\text { Объем рубок } \\
\text { ухода } \\
Q_{P y} \text {, тыс. м }\end{array}$ & $\begin{array}{c}\text { Объем } \\
\text { заготовки } \\
\text { плодов } \\
\text { и ягод } \\
Q_{\text {Пя }}, \text { ц }\end{array}$ & $\begin{array}{c}\text { Объем } \\
\text { заготовки } \\
\text { лекарств. } \\
\text { сырья } \\
Q_{\text {ЛС }}, \text { ц }\end{array}$ & $\begin{array}{c}\text { Валовой } \\
\text { выход } \\
\text { сена } \\
Q_{C}, \text { т }\end{array}$ & $\begin{array}{l}\text { Объем } \\
\text { медо- } \\
\text { сбора } \\
Q_{m}, \mathrm{~T}\end{array}$ & $\begin{array}{c}\text { Кол-во } \\
\text { пчело } \\
\text { семей } \\
N_{\Pi C}, \\
\text { шт. }\end{array}$ \\
\hline Бакалинский & 63.894 & 19.120 & 29.9104 & 78.03 & 6.65 & 465.444 & 71.898 & 3121 \\
\hline Белебеевский & 68.816 & 11.859 & 15.3548 & 50.99 & 6.18 & 243.150 & 48.493 & 1901 \\
\hline Бижбулякский & 34.499 & 0.568 & 9.1416 & 21.50 & 4.61 & 138.300 & 30.379 & 1218 \\
\hline Ермекеевский & 21.738 & 13.072 & 6.7686 & 10.74 & 3.43 & 802.200 & 59.563 & 2006 \\
\hline Миякин & 39.909 & 8.550 & 10.9030 & 20.50 & 3.76 & 265.311 & 43.479 & 1519 \\
\hline Туймази & 74.431 & 25.012 & & 66. & 10.50 & 325.767 & & 2143 \\
\hline Шаранский & 35.118 & 8.440 & 10.9427 & 12.48 & 2.47 & 150.800 & 32.696 & 1378 \\
\hline
\end{tabular}

Методика ранжирования. У любых факторов имеется четкая векторная ориентация. Любой человек понимает направленность количественных изменений в сельском хозяйстве.

Каждый человек стремится к лучшему в жизни, поэтому возможны всего два варианта векторов поведения [1-5]:

a) лучше меньше (да лучше, символ $\downarrow$ по вектору «лучше $\rightarrow$ хуже»);

б) лучше больше (и это благо, поэтому принимается символ $\uparrow$ ).

Взаимосвязь фактора от самого себя определяется ранговым распределением, то есть это - монарное отношение. Оно показывает добротность исходных данных и служит для проверки их достоверности и добротности по коэффициенту корреляции $R$-распределений $y=f(R=0,1,2,3, \ldots)$. Ранги удобно использовать вместо факторов, так как снимают математическую проблему «проклятия размерности», например, при рейтинге показателей. 
Результат рангового распределения приведен в таблицах 3, 4 и 5.

Таблица 3

Ранговые распределения категорий земель

на Бугульминско-Белебеевской возвышенности

\begin{tabular}{|c|c|c|c|c|c|c|c|c|c|c|}
\hline \multirow[t]{2}{*}{ Район } & \multicolumn{2}{|c|}{$\begin{array}{c}\text { Общая } \\
\text { площадь, } \\
\text { тыс. га } \\
\end{array}$} & \multicolumn{2}{|c|}{$\begin{array}{c}\text { Земли сельхоз. } \\
\text { назначения } \\
\text { тыс. га }\end{array}$} & \multicolumn{2}{|c|}{$\begin{array}{c}\text { Площадь } \\
\text { лесного фонда, } \\
\text { тыс. га } \\
\end{array}$} & \multicolumn{2}{|c|}{$\begin{array}{c}\text { Площадь } \\
\text { липняков, } \\
\text { тыс. га }\end{array}$} & \multicolumn{2}{|c|}{$\begin{array}{c}\text { Прочие } \\
\text { земли, } \\
\text { тыс. га }\end{array}$} \\
\hline & $R_{S}$ & $S \uparrow$ & $R_{C X Y}$ & $S_{c x y} \downarrow$ & $R_{Л \Phi}$ & $S_{\text {ЛФ }} \uparrow$ & $R_{Л}$ & $S_{J} \uparrow$ & $R_{n p}$ & $S_{n p} \downarrow$ \\
\hline Бакалинский & 3 & 195.08 & 3 & 119.70 & 2 & 63.894 & 1 & 19.120 & 2 & 11.490 \\
\hline Белебеевский & 4 & 185.58 & 1 & 107.82 & 1 & 68.816 & 3 & 11.859 & 1 & 8.937 \\
\hline Бижбулякский & 1 & 213.39 & 6 & 160.08 & 5 & 34.499 & 6 & 0.568 & 5 & 18.815 \\
\hline Ермекеевский & 5 & 143.43 & 2 & 109.58 & 6 & 21.738 & 2 & 13.072 & 3 & 12.114 \\
\hline Миякинский & 2 & 205.13 & 5 & 150.82 & 3 & 39.909 & 4 & 8.550 & 4 & 14.396 \\
\hline Туймазинский & 0 & 235.78 & 4 & 136.77 & 0 & 74.431 & 0 & 25.012 & 6 & 24.577 \\
\hline Шаранский & 6 & 138.42 & 0 & 95.75 & 4 & 35.118 & 5 & 8.440 & 0 & 7.548 \\
\hline
\end{tabular}

Таблица 4

Ранговые распределения категорий земель лесного фонда

на Бугульминско-Белебеевской возвышенности

\begin{tabular}{|c|c|c|c|c|c|c|c|c|c|c|c|c|}
\hline \multirow{2}{*}{ Район } & \multicolumn{2}{|c|}{$\begin{array}{l}\text { Лесопокры- } \\
\text { тые, тыс. га }\end{array}$} & \multicolumn{2}{|c|}{$\begin{array}{c}\text { Редины, } \\
\text { га } \\
\end{array}$} & \multicolumn{2}{|c|}{$\begin{array}{c}\text { Вырубки, } \\
\text { га }\end{array}$} & \multicolumn{2}{|c|}{$\begin{array}{c}\text { Прогалины, } \\
\text { га } \\
\end{array}$} & \multicolumn{2}{|c|}{$\begin{array}{c}\text { Сенокосы } \\
\text { тыс. га }\end{array}$} & \multicolumn{2}{|c|}{$\begin{array}{c}\text { Пастбища, } \\
\text { тыс. га }\end{array}$} \\
\hline & $R_{\text {лn }}$ & $S_{I n} \uparrow$ & $R_{p}$ & $S_{p} \downarrow$ & $R_{b}$ & $S_{\theta} \downarrow$ & $R_{n p}$ & $S_{n p} \downarrow$ & $R_{c}$ & $S_{c} \uparrow$ & $R_{n}$ & $S_{n} \downarrow$ \\
\hline Бакалинский & 2 & 59.930 & 2 & 39 & 5 & 1063 & 2 & 176 & 1 & 1.543 & 4 & 1.011 \\
\hline Белебеег & 1 & 63.093 & 3 & 65 & 4 & 889 & 4 & 279 & 2 & 1.328 & 5 & 1.046 \\
\hline Бижбулякский & 4 & 32.520 & 4 & 91 & 2 & 276 & 5 & 381 & 4 & 0.707 & 2 & 0.524 \\
\hline Ермекеевс & 6 & 15.098 & 0 & 15 & 0 & 94 & 1 & 104 & 6 & 0.415 & 1 & 0.510 \\
\hline Миякинский & 5 & 30.329 & 6 & 104 & 1 & 265 & 3 & 214 & 3 & 1.195 & 3 & 0.636 \\
\hline Туймазинский & 0 & 68.389 & 5 & 97 & 6 & 1186 & 6 & 524 & 0 & 2.669 & 6 & 1.545 \\
\hline Шаранский & 3 & 33.780 & 1 & 24 & 3 & 431 & 0 & 50 & 5 & 0.423 & 0 & 0.403 \\
\hline
\end{tabular}

Таблица 5

Ранговые распределения параметров заготовки побочной продукции леса на Бугульминско-Белебеевской возвышенности

\begin{tabular}{|c|c|c|c|c|c|c|c|c|c|c|c|c|}
\hline \multirow[t]{2}{*}{ Район } & \multicolumn{2}{|c|}{$\begin{array}{c}\text { Объем } \\
\text { рубок ухода, } \\
\text { тыс. }{ }^{3}\end{array}$} & \multicolumn{2}{|c|}{$\begin{array}{c}\text { Объем заго- } \\
\text { товки плодов } \\
\text { и ягод, ц }\end{array}$} & \multicolumn{2}{|c|}{$\begin{array}{c}\text { Объем заго- } \\
\text { товки лекар. } \\
\text { сырья, ц }\end{array}$} & \multicolumn{2}{|c|}{$\begin{array}{c}\text { Валовой вы- } \\
\text { ход } \\
\text { сена, т }\end{array}$} & \multicolumn{2}{|c|}{$\begin{array}{c}\text { Объем } \\
\text { медосбора, т }\end{array}$} & \multicolumn{2}{|c|}{$\begin{array}{c}\text { Количество } \\
\text { пчело- } \\
\text { семей, шт. }\end{array}$} \\
\hline & $R_{P y}$ & $Q_{P Y} \uparrow$ & $R_{\text {ПЯ }}$ & $Q_{\text {Пя }} \uparrow$ & $R_{\text {ЛC }}$ & $Q_{\text {ЛС }} \uparrow$ & $R_{C}$ & $Q_{C} \uparrow$ & $R_{\mu}$ & $Q_{\mu} \uparrow$ & $R_{\Pi C}$ & $N_{\Pi C} \uparrow$ \\
\hline Бакалинский & 0 & 29.9104 & 0 & 78.03 & 1 & 6.65 & 1 & 465.444 & 0 & 71.898 & 0 & 3121 \\
\hline Белебеевский & 2 & 15.3548 & 2 & 50.99 & 2 & 6.18 & 4 & 243.150 & 2 & 48.493 & 3 & 1901 \\
\hline Бижбулякский & 5 & 9.1416 & 3 & 21.50 & 3 & 4.61 & 6 & 138.300 & 6 & 30.379 & 6 & 1218 \\
\hline Ермекеевский & 6 & 6.7686 & 6 & 10.74 & 5 & 3.43 & 0 & 802.200 & 1 & 59.563 & 2 & 2006 \\
\hline Миякинский & 4 & 10.9030 & 4 & 20.50 & 4 & 3.76 & 3 & 265.311 & 4 & 43.479 & 4 & 1519 \\
\hline Туймазинский & 1 & 18.3007 & 1 & 66.40 & 0 & 10.50 & 2 & 325.767 & 3 & 46.477 & 1 & 2143 \\
\hline Шаранский & 3 & 10.9427 & 5 & 12.48 & 6 & 2.47 & 5 & 150.800 & 5 & 32.696 & 5 & 1378 \\
\hline
\end{tabular}

Например, по фактору «Общая площадь района» $S \uparrow$, в программной среде Excel в функции $=\mathrm{PAH \Gamma}(\mathrm{S} 1 ; \mathrm{S} \$ 1: \mathrm{S} \$ 8 ; 0)$ для первого фактора приняты следующие условные обозначения: S1 - идентификатор ранжируемого второго столбца и первой строки; $\mathbf{S} \$ 1$ - первая строка ранжируемого столбца; $\mathbf{S} \$ 8$ - последняя строка ранжируемого столбца по данным таблицы 3; $0 \vee 1$ - ранжиро- 
вание по убыванию (0) или возрастанию (1). Ранги изменяются от нуля, поэтому придется из результатов ранжирования в программной среде Excel вычитать единицу.

Рейтинг факторов по рангам. Приведение всех показателей к вектору «лучше $\rightarrow$ хуже» дает возможность суммирования всех рангов и по их сумме провести рейтинг. При этом сумма рангов исключает размерность факторов.

Для составления рейтинга из данных таблицы 5 принимаем только ранги параметров и поставим их в таблицы 6 и 7.

Таблица 6

Рейтинг рангов категорий земель и категорий земель лесного фонда на Бугульминско-Белебеевской возвышенности

\begin{tabular}{|l|c|c|c|c|c|c|c|c|c|c|c|}
\hline \multicolumn{1}{|c|}{ Район } & $R_{S}$ & $R_{C X У}$ & $R_{Л \Phi}$ & $R_{Л}$ & $R_{n p}$ & $R_{л n}$ & $R_{p}$ & $R_{6}$ & $R_{n p}$ & $R_{c}$ & $R_{n}$ \\
\hline Бакалинский & 3 & 3 & 2 & 1 & 2 & 2 & 2 & 5 & 2 & 1 & 4 \\
\hline Белебеевский & 4 & 1 & 1 & 3 & 1 & 1 & 3 & 4 & 4 & 2 & 5 \\
\hline Бижбулякский & 1 & 6 & 5 & 6 & 5 & 4 & 4 & 2 & 5 & 4 & 2 \\
\hline Ермекеевский & 5 & 2 & 6 & 2 & 3 & 6 & 0 & 0 & 1 & 6 & 1 \\
\hline Миякинский & 2 & 5 & 3 & 4 & 4 & 5 & 6 & 1 & 3 & 3 & 3 \\
\hline Туймазинский & 0 & 4 & 0 & 0 & 6 & 0 & 5 & 6 & 6 & 0 & 6 \\
\hline Шаранский & 6 & 0 & 4 & 5 & 0 & 3 & 1 & 3 & 0 & 5 & 0 \\
\hline Сумма $\sum R$ & 21 & 21 & 21 & 21 & 21 & 21 & 21 & 21 & 21 & 21 & 21 \\
\hline \multicolumn{1}{|c|}{$\sum I_{y}$} & 1 & 1 & 1 & 1 & 1 & 1 & 1 & 1 & 1 & 1 & 1 \\
\hline
\end{tabular}

Таблица 7

Рейтинг рангов параметров заготовки побочной продукции леса на Бугульминско-Белебеевской возвышенности

\begin{tabular}{|l|c|c|c|c|c|c|c|c|}
\hline \multicolumn{1}{|c|}{ Район } & $R_{P У}$ & $R_{\text {ПЯ }}$ & $R_{\text {ЛС }}$ & $R_{C}$ & $R_{м}$ & $R_{\text {ПС }}$ & $\sum R$ & $\begin{array}{c}\text { Место } \\
I_{л}\end{array}$ \\
\hline Бакалинский & 0 & 0 & 1 & 1 & 0 & 0 & 29 & 1 \\
\hline Белебеевский & 2 & 2 & 2 & 4 & 2 & 3 & 44 & 3 \\
\hline Бижбулякский & 5 & 3 & 3 & 6 & 6 & 6 & 73 & 7 \\
\hline Ермекеевский & 6 & 6 & 5 & 0 & 1 & 2 & 52 & 4 \\
\hline Миякинский & 4 & 4 & 4 & 3 & 4 & 4 & 62 & 6 \\
\hline Туймазинский & 1 & 1 & 0 & 2 & 3 & 1 & 41 & 2 \\
\hline Шаранский & 3 & 5 & 6 & 5 & 5 & 5 & 56 & 5 \\
\hline Сумма $\sum R$ & 21 & 21 & 21 & 21 & 21 & 21 & 357 & - \\
\hline Место $I_{y}$ & 1 & 1 & 1 & 1 & 1 & 1 & - & - \\
\hline
\end{tabular}

Далее суммированием рангов по 17 столбцам определяем сумму рангов $\sum R$ и по росту этой суммы расставляем места рейтинга районов. Из данных таблиц видно, что с экологических позиций самыми лучшими стали Бакалинский (1 место), Туймазинский (2 место) и Белебеевский (3 место) район. Поэтому без статистического моделирования можно выявить значимость каждого из 17 факторов.

Ранговые распределения. Все 17 ранговых распределений подчиняются общему экспоненциальному закону гибели или роста по формуле

$$
Y=a \exp \left( \pm b R_{Y}{ }^{c}\right) .
$$


При этом коэффициент корреляции у всех закономерностей выше 0,95 и это соответствует уровню адекватности сверхсильные факторные связи. Поэтому таблицы 1 и 2 с исходными данными составлены добротно, и они являются высокоточными, а выводы по закономерностям вполне достоверными.

Рассмотрим графики и уравнения рейтинга по всем 17 факторам:

- общей площади района

$$
S=238,75779 \exp \left(-0,033742 R_{S}{ }^{1,52647}\right) ;
$$

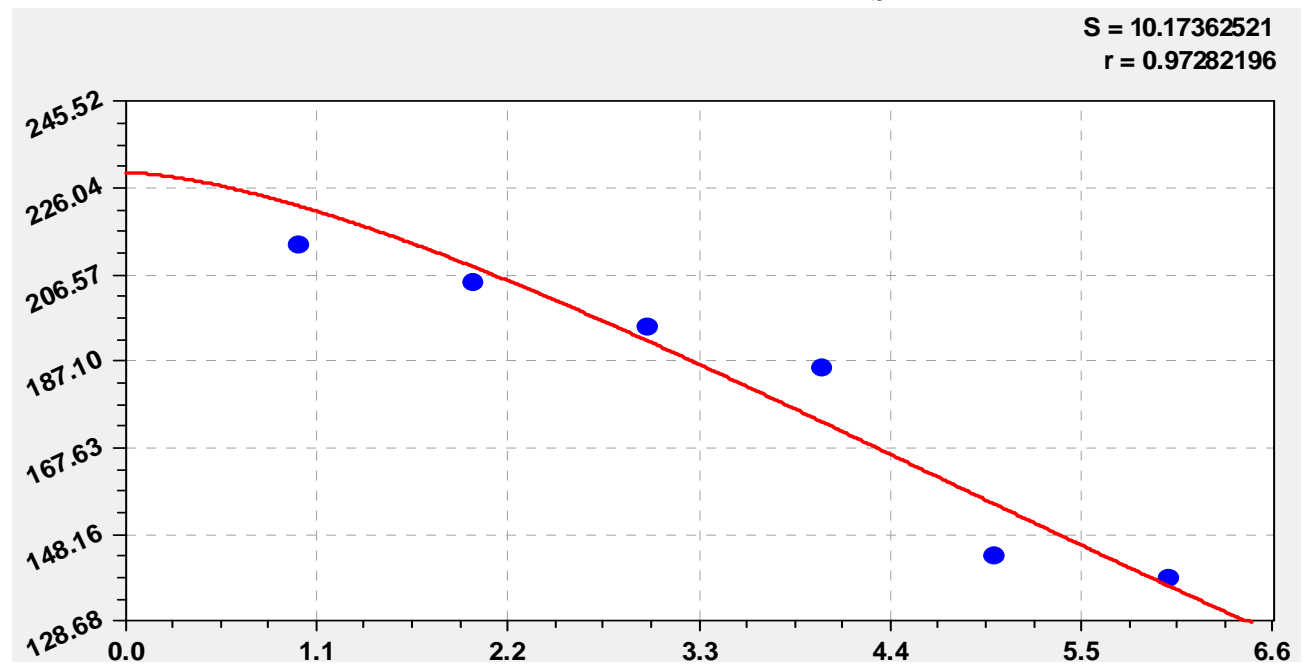

Рисунок 2. График рангового распределения общей площади районов

- земель сельскохозяйственного назначения

$$
S_{C X Y}=96,55833 \exp \left(0,072534 R_{C X Y}{ }^{1,09760}\right) ;
$$

- площади лесного фонда

$$
S_{Л \Phi}=75,70297 \exp \left(-0,10456 R_{Л \Phi}^{1,37115}\right) ;
$$

- площади липняков

$$
S_{Л}=24,77356 \exp \left(-0,25115 R_{J}^{1,09375}\right) ;
$$

- прочие земли

$$
S_{n p}=8,13769 \exp \left(0,085453 R_{n p}{ }^{1,42406}\right) ;
$$

- лесопокрытые земли лесного фонда

$$
S_{\text {лп }}=69,36287 \exp \left(-0,093109 R_{\text {лп }}^{1,50467}\right) ;
$$

- лесные редины

$$
S_{p}=9,78634 \exp \left(1,18962 R_{p}^{0,40018}\right) ;
$$

- вырубки

$$
S_{6}=56,49220 \exp \left(1,37749 R_{6}^{0,45370}\right) ;
$$

- прогалины

$$
S_{n p}=59,17467 \exp \left(0,56297 R_{n p}^{0,75156}\right) ;
$$

- сенокосы в лесу

- пастбища в лесу

$$
S_{c}=2,64388 \exp \left(-0,44002 R_{c}^{0,77094}\right) ;
$$

$$
S_{n}=0,41813 \exp \left(0,11128 R_{n}^{1,36812}\right) ;
$$



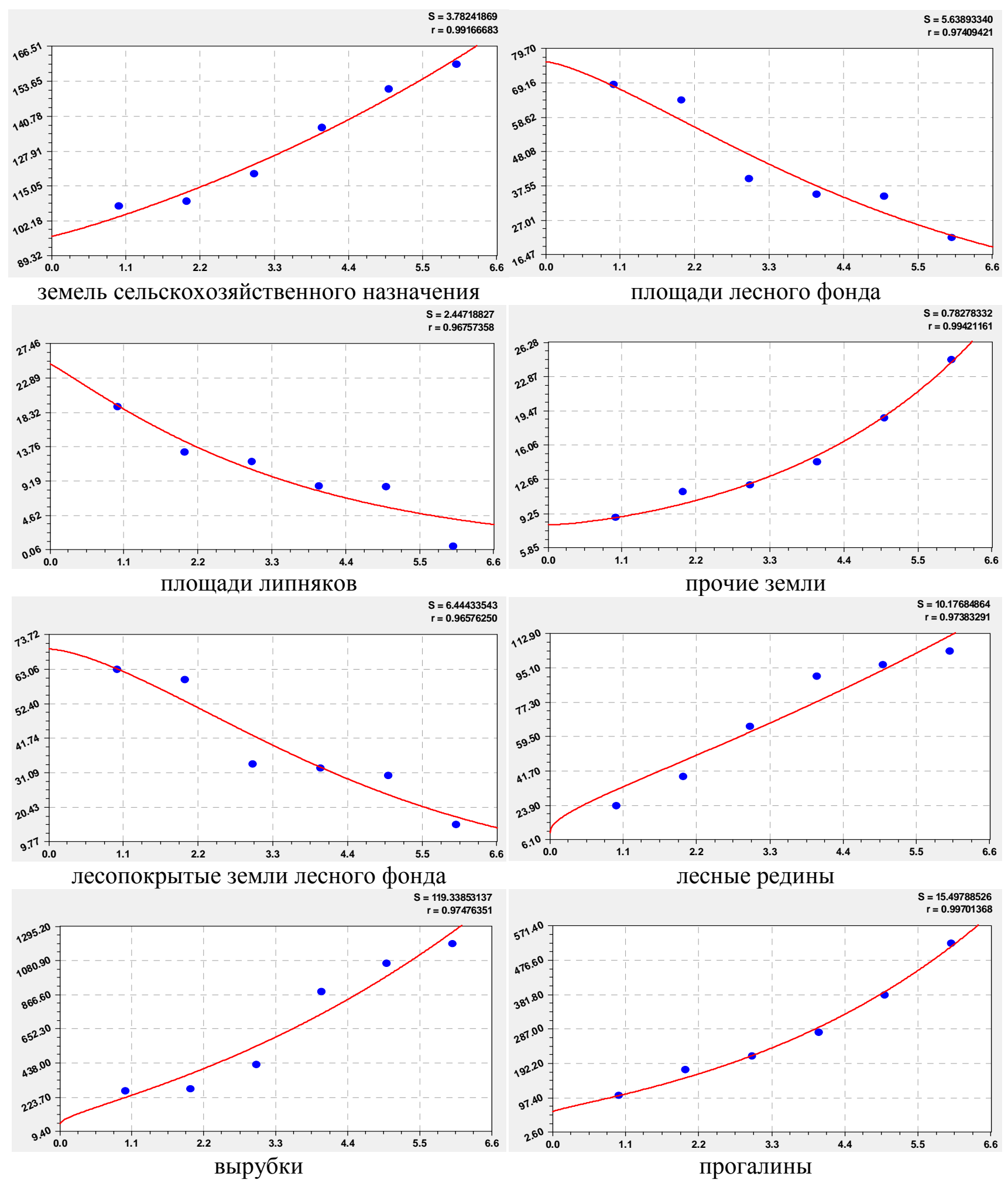

Рисунок 3. Графики ранговых распределений показателей

- объем рубок ухода за лесом

$$
S_{P У}=29,88262 \exp \left(-0,47258 R_{P У}^{0,59932}\right) ;
$$

- объем заготовки плодов и ягод

$$
S_{\text {ПЯ }}=79,37227 \exp \left(-0,20378 R_{\text {ПЯ }}^{1,40112}\right) ;
$$

- объем заготовки лекарственного сырья

$$
S_{\text {ЛС }}=10,44670 \exp \left(-0,38610 R_{\text {ЛС }}{ }^{0,68692}\right) ;
$$



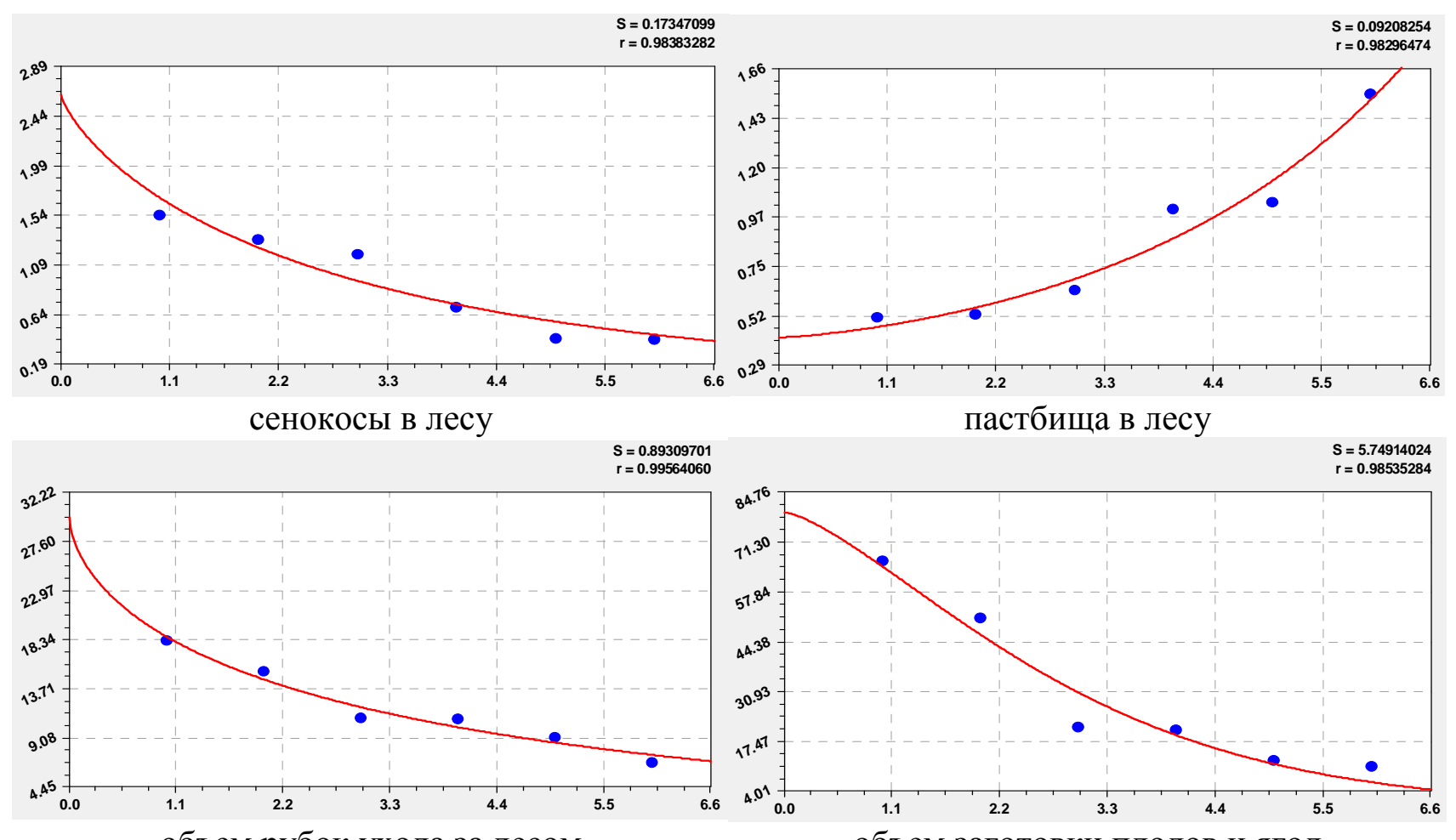

объем рубок ухода за лесом

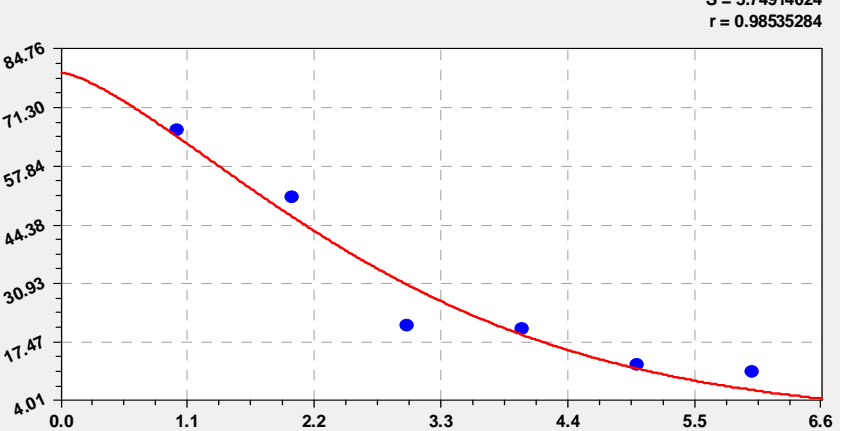

объем заготовки плодов и ягод

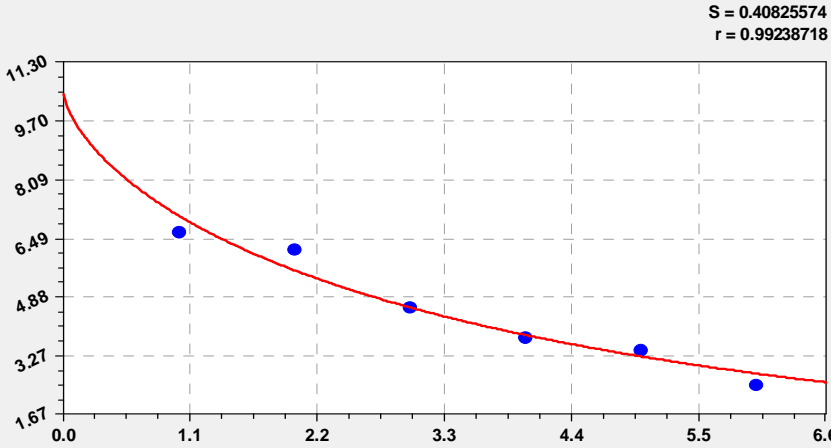

объем заготовки лекарственного сырья

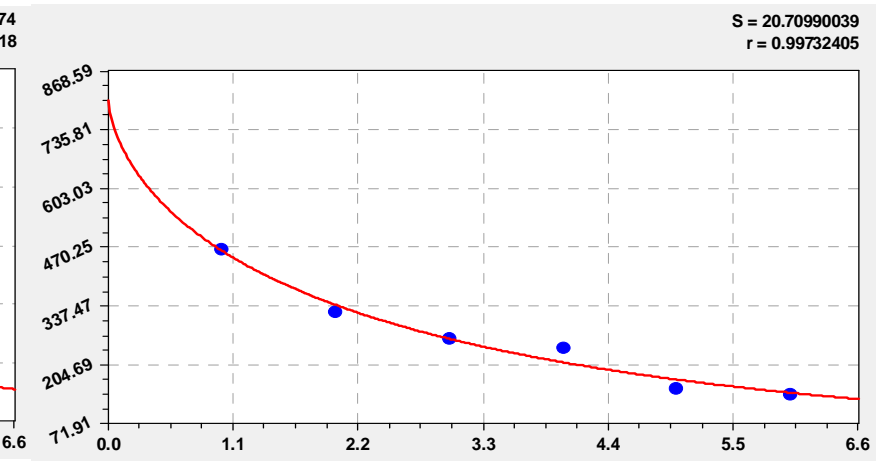
$\mathrm{S}=2.83328551$
$\mathrm{r}=0.98728974$

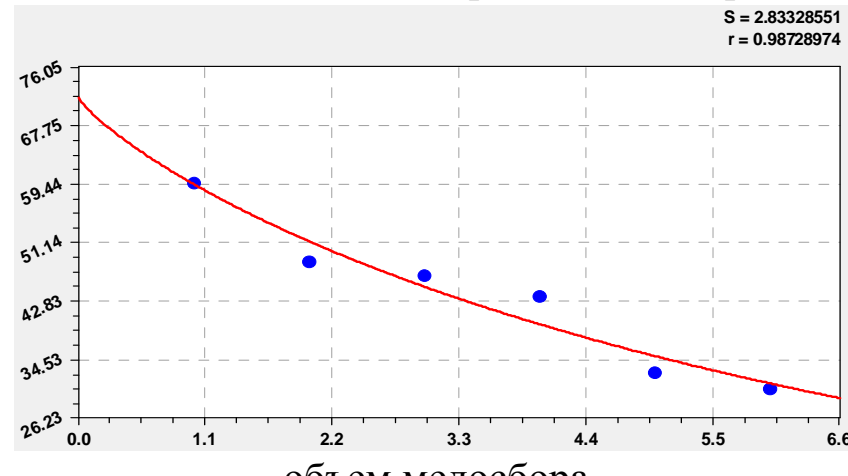

объем медосбора

валовой выход сена

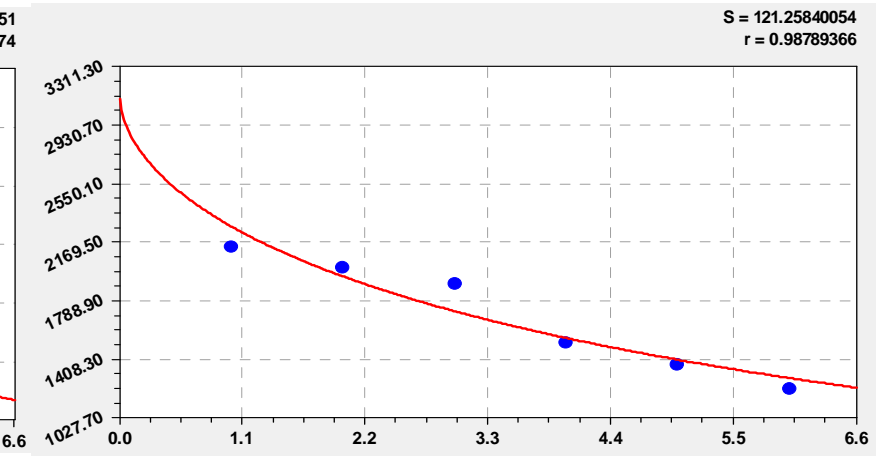

количество пчелосемей

Рисунок 4. Графики ранговых распределений остальных показателей

- валовой выход сена

$$
S_{C}=802,10962 \exp \left(-0,55125 R_{C}^{0,63924}\right) ;
$$

- объем медосбора

$$
S_{M}=71,68781 \exp \left(-0,18798 R_{M}{ }^{0,83080}\right) ;
$$

- количество пчелосемей

$$
S_{\text {ПС }}=3105,1913 \exp \left(-0,31210 R_{\Pi C}^{0,57869}\right) .
$$


По убыванию коэффициента корреляции рейтинг добротности измерений у учтенных факторов следующий:
1) объем заготовки сена 0,9973 ;
10) сенокосы 0,9838 ;
2) прогалины леса 0,9970 ;
3) объем рубок ухода 0,9956 ;
11) пастбища 0,9830 ;
4) прочие земли 0,9942 ;
12) вырубки 0,9748 ;
5) объем лекарственного сырья 0,9924;
13) площадь лесного фонда 0,9741 ;
14) редины 0,9738 ;
6) площадь сельхозугодий 0,9917 ;
15) общая площадь района 0,9728 ;
7) количество пчелосемей 0,9879 ;
16) площадь липняков 0,9676 ;
8) объем медосбора 0,9873 ;
9) объем плодов и ягод 0,9854 ;
17) лесопокрытые площади ЛФ 0,9658 .

Из вышеприведенного списка видно, теснота связи сильнейшая по коэффициенту корреляции боле 0,96 .

Заключение. Рейтинг семи (минимальное количество для моделирования) районов Бугульминско-Белебеевской возвышенности показал, что выбранные 17 показателей оказались добротными по погрешности измерений. Однако этот отбор был выполнен эвристически, на основе интуиции. Поэтому в дальнейшем можно продолжить исследования в двух направлениях:

1) расширить список показателей, чтобы отбор наилучших из них проводить на основе применения метода факторного анализа;

2) представленные в данной статье 17 показателей распространить на все сельские районы Республики Башкортостан, чтобы по изложенному методу получить полный рейтинг муниципалитетов по показателям наличия, заготовки и переработки недревесного сырья.

\section{Список литературы:}

1. Арзамасцев А.Д., Мазуркин П.М., Максимец Н.В. Факторный анализ сельскохозяйственного производства. Йошкар-Ола: МарГТУ, 2009. 388 с.

2. Мазуркин П.М., Михайлова С.И. Биотехническая оценка пойменного луга. М.: Изд-во «Академия естествознания», 2009. 279 с.

3. Мазуркин П.М., Михайлова С.И. Модели кадастровой оценки сельхозугодий // АПК: Экономика и управление. 2009. № 8. С.76-82.

4. Мазуркин П. М., Михайлова С.И. Территориальное экологическое равновесие $=$ Territprial ecological balance: аналит. обзор; Учреждение Рос. акад. наук Гос. публич. науч.-техн. б-ка Сиб. отд-ния РАН. Новосибирск: ГПНТБ СО РАН, 2010. 430 с. (Сер. Экология. Вып. 94).

5. Михайлова С.И., Мазуркин П.М. Ландшафтно-экологическая роль пойменного луга малых рек. Йошкар-Ола: МарГТУ, 2011. 154 с.

6. Хисамов Р.Р. Хозяйственно-ценный фитоценоз в защитных лесных насаждениях на агроландшафтах Белебеевской возвышенности Республики Башкортостан / Хисамов Р.Р., Рахматуллина И.Р., Рахматуллин 3.3., Хасанов Ф.Ф. // Материалы международной научно-практической конференции «Сберегающие (биологическое) земледелие в современном сельском хозяйстве». Уфа: Гилем, Башк.энцикл., 2014. 244 с.

7. Хисамов Р.Р., Кулагин А.А. Биологические ресурсы Республики Башкортостан: недревесные ресурсы леса. Уфа: Изд-во БГПУ, 2014. 292 с. 